INDO GLOBAL JOURNAL OF

PHARMACEUTICAL SCIENCES

ISSN 2249- 1023

\title{
Comparative Analysis of Secondary Metabolites and Protein Variations in Two Different Species of Calotropis
}

\author{
Navdeep Ranjan, Sushil Kumar Singh \\ Department of Biotechnology, A. N. College, Patna, Bihar, India
}

Address for Correspondance: Navdeep Ranjan, nav2deep@gmail.com ; Sushil Kumar Singh, sushilaaryaka@gmail.com

\begin{abstract}
Keywords
Calotropis procera; Calotropis

gigantea;

Secondary

Metabolites;

Proteins; Isolation of Protein; Bradford Method; SDS-

PAGE.
\end{abstract}

\begin{abstract}
Calotropis (family: Asclepiadaceae) is a plant growing in the wild and has been used in the traditional medicinal system for the treatment of various diseases. In present study, the analysis of secondary metabolites of both the species viz; Calotropis procera and Calotropis gigantea has been done. Protein is isolated from the leaves of the Calotropis procera and Calotropis gigantea and estimated the concentration of protein by Bradford method. Further the variations of protein are analyzed by SDS- PAGE. Petroleum ether extracts of both the species show the presence of Glycoside only. While methanolic extract of both the species show the presence of Alkaloids, Flavonoids, Tannin \& Phenols, Proteins \& Amino Acid and Triterpenoids \& Steroids. Protein concentration is high in Calotropis gigantea while low in Calotropis procera. SDS-PAGE showing the variations of protein band. Calotropis gigantea shows 10 bands of protein while Calotropis procera shows 7 bands. These variant protein bands also show differences with respect to their mol. Wt. which may be due to the presence of some different protein being expressed in that particular location. These variations should be properly scientifically studied further using larger number of samples covering a larger area and should be evaluated phytochemically and pharmacologically to enable a better use of plant for therapeutic use in traditional medicines (C) 2016 iGlobal Research and Publishing Foundation. All rights reserved.
\end{abstract}

Conference Proceedings: International Conference on Advances in Plant and Microbial Biotechnology (PMB-2017); JIIT, Noida: February 02-04, 2017

Indo Global Journal of Pharmaceutical Sciences( ISSN 22491023 ; CODEN- IGJPAI; NLM ID: 101610675) indexed and abstracted in EMBASE(Elsevier), SCIRUS(Elsevier),CABI, CAB Abstracts, Chemical Abstract Services(CAS), American Chemical Society(ACS), Index Copernicus, EBSCO, DOAJ, Google Scholar and many more. For further details, visit http://iglobaljournal.com 